\title{
Effects of Social Media Brand Reviews on Trust and Brand Perception: An Experimental Study on Facebook in Pakistani context
}

\author{
Junaid Saddique*, Imran Qureshi, Atif Shabbir \\ International Islamic University Islamabad
}

\begin{abstract}
Attraction towards social networking sites is increasing day by day. People join social networking sites to communicate with their friends, share their feelings and gain information from different platforms. One of the most popular social networking sites is Facebook with 1.7 billion active users. However, there are many users of Facebook with fake identities, communicating with other users just for fun and enjoyment. Companies are also attracted towards Facebook for advertisement, consumer engagement and feedbacks of customers bearing very low cost. However, users with fake identities also like different products and leave their comments on different brand pages. So companies are unable to get true picture of customer's feedback and these fake reviews also damage trust of other customers. Current study examined the effect of brand page reviews on customer's trust, perceived risk and perceived benefit. Both fake and original comments were considered in study. Effect of reviews is tested on three types of trust (interpersonal trust, dispositional trust and institutional trust). Experimental approach was used to collect data from 300 participants. Regression analysis was used to test the hypotheses of study. Results show that people believe more in comments and information provided by their friends or by third party. While getting information from social media, users trust comments and reviews provided by other users without differentiating original and fake comments. Users of Facebook trust in brand but normally ignore information provided by company itself. Furthermore, other users of social networking sites are affected by comments and reviews. Managerial implications are also discussed.
\end{abstract}

\section{Introduction}

Social media is leading new media for the last decade or so. People have got new ways to communicate with one another such as blogs, social networking websites, etc. After discovering social media, social networking sites (SNS) have introduced new methods of communications in different directions. Open communication forums are being used by different sites, such as Twitter and Facebook to support and maintain conversation among their users (Nelson-Field et al., 2012). Furthermore, social networking sites also allow their users to communicate with businesses and companies directly, which help companies and businesses to interact with their customers and take their feedback. The most popular social networking website is Facebook.com (Nelson-Field et al., 2012), with over one billion profiles worldwide (Facebook, 2013). However, many people use Facebook for fun and enjoyment (Qureshi and Mir, 2013) which sometime created problem for different organization and even for other people. On 2nd of Dec. 2014 Dawn reported that "fake Facebook accounts used to be a problem faced by teenage girls, but it appears that in Pakistan, they are also becoming

*Corresponding author.

Email: junaidpac@gmail.com a bother for the military and the Inter-Services Intelligence (ISI)" (Dawn, 2014). A formal complaint was registered by ISI and the military to Pakistan Telecommunication Authority (PTA) and Ministry of Information Technology (MOIT) that there was existence of fake accounts on social networking sites with the name of their chiefs. So many people join social media just for fun however other join social media for purpose of information. Information provided by other consumers may increase trust and reduce perceived risk. Trust is an ongoing issue in e-commerce (Gefen et al., 2011) and can be increased by social commerce and social support. In fact, to endorse trust in an online context, there is a need to provide credible signals to re-assure e-vendors (Ba and Pavlou, 2002).

Most of the companies are engaging customers by advertising on social media. So a lot of researchers have calculated brand engagement in social media through different means and according to them counting of likes and comments on Facebook presents brand engagement (Chauhan et al., 2013; Hoffman and Fodor, 2010; Malbon, 2013). On the other hand, different researchers have explored the use of Facebook. According to some studies, people like a brand because of self-expression; while others say that users like brands to create relation- 
ships with other users. However, the main purpose is to enter a platform to chat with other people (Back et al., 2010; Schau and Gilly, 2003); Lipsman et al., 2012; Trusv et al., 2009; (Nelson-Field et al., 2012). Thus, brand engagement based on the counting of likes does not give a clear picture.

In Pakistani context there may be another reason because of which brand engagement cannot provide a clear picture. Basically, people like and comment on a brand page for self-expression, while using social media (Tariq et al., 2012). However, researchers have only explored the likes and comments on brand pages but they were unable to explore whether it affects trust and perception or not. A few researchers have studied the intentions of users to use facebook in Pakistan and they found that people in Pakistan use facebook for enjoyment and information (Qureshi and Mir, 2013). People who use facebook for enjoyment purpose have fake identities on facebook (Tariq et al., 2012) as people like and comment on brand pages/forums for selfexpression (Nelson-Field et al., 2012). So people with fake identities also like and comment on brands, which is not a true picture of brand engagement.

If a person without prior knowledge wants to buy a product, he/she will consult his/her friends or will use online sources to gain information. In latter case other customers' reviews have an effect on his decision making (Malbon, 2013). Therefore, word of mouth way of communication has been of interest to marketing personnel for some time (Anderson, 1998; Richins, 1984). Consequently, customers trust on online comments of other customers while making decisions. However, fake users on Facebook and their comments on brand pages also have an impact on another customer's decision.

In current research, reviews are indication of visitors of brand page. These signals are found to be strong predictor of trustworthiness (Utz et al., 2012). A survey stated that 70 Percent of consumers trust the reviews from other people (Nielsen, 2009). Different researches have worked on trust in online reviews (Racherla et al., 2012; Sparks and Browning, 2011; Sparks et al., 2013). However, there are previous researches on trust in fake reviews (Lappas et al., 2016; Liu, 2013; Mukherjee et al., 2012). Furthermore, there is no previous research on trust effecting perceived risk and perceived benefit regarding social media. Trust and risk are treated differently by different researches. However, majority have stated risk as outcome of trust (Ivanov and Ganev, 2014; Kim et al., 2008; Nooteboom et al., 1997).

Quite a lot of researches have been conducted on social media in different aspects. Many researchers have worked on "likes" of brands in social media (Lin and Lu, 2011; Phua and Ahn, 2014); while some others have worked on behavior of social media users (Hajli, 2015; Liang and Turban, 2011); (Fue, Li, \& Wenyu, 2009). However, trust is topic of interest for many scholars (Coppola et al., 2004; Jarvenpaa et al., 1999); (Meyerson,
1996; Piccoli \& Ives, 2003). In Pakistani context, there is no research, including the trust of customers on fake comments and their perception.

The purpose of current study is to gauge the effects of online comments on customer's trust, perceived benefit and perceived risk. Most of the researchers have conducted limited researches on consequences and antecedents of trust. A gap exists in linking the consequences of online trust to perceived benefit and perceived risk of services and products in social media. Similarly, most of the researches are limited to western context and mostly focusing on US (Ba and Pavlou, 2002; Ba et al., 1999; Castelfranchi, 2003; Tan and Thoen, 2000). Theories developed for the western culture might not be applicable in other societies, especially since the culture is affecting the outcome of trust (Sako and Helper, 1998). Several study findings have posited that perceptions of trust differ from culture to culture, the way in which it was formed and the way of conceptualization (Sako and Helper, 1998). Therefore, there is a need to re-examine the concept of trust and its outcome in different cultures and markets (Lee and Turban, 2001).

\subsection{Background of Facebook}

Social networking sites especially Facebook has been converted to a cultural phenomenon (Nelson-Field et al., 2012) so quickly, but the research on social networking is not as ample as it should be. This is because of the changing nature of the websites, as well as the mostly individual experience of the site, that each user may encounter. Facebook has re-shaped cultural communication through diverse public (status update, wall post) so it is very important to study Facebook (Smock et al., 2011). Users of Facebook can communicate to each other throughout the world by updating status, wall posts, instant messenger and private messengers. Depending on the nature of desirious knowledge there are many theoretical frameworks producing different perspectives. For example, gratification theory is one popular theory related to Facebook, which explains why different users use various sites (Socket et al., 2011); (Tosun, 2012; Wang et al., 2012).

Companies need to connect and create a relationship with their consumers to understand human psychology. So they use Facebook as mode of communication with their customers. So from a practitioner and an academic perspective it is very important to study the relationship of organization and public.

So it's an attractive field for researchers to create brand engagement for customers through social media. Vast research has been conducted to study the brand engagement through social networking site, i.e. Facebook (Ellison et al., 2007; Kim et al., 2008; Smith et al., 2005). Companies are forced to get involved in social media so that customer can get engaged in specific brand. Com- 
panies involve customers to respond by enhancing their offerings, handling problems and providing better service (Gummerus et al., 2012; Van Doorn et al., 2010). Over the past few years, brands have embraced social networking sites, i.e. Facebook as a key marketing channel to drive engagement and brand awareness (Malhotra et al., 2013).

\subsection{Fake and Original Comments}

Companies are collecting data from direct feedback loop of social media. Furthermore, some companies involve their customers in decision making for example Samsung modified the position of speakers of flat-screen TV by using online comments of customers (Klassen, 2009). Approximately 83\% of Fortune 500 companies use some form of social media to connect and engage with consumers in the marketplace (Naylor et al., 2012). Brand engagement is one of the emerging topics for the managers of diverse industries and markets who aim to improve their company performance (Gummerus et al., 2012; Sashi, 2012).

Companies are moving toward Facebook by creating their brand page. With the help of their page they can cut down their advertising cost. Brand pages can be updated by posting new pictures and links, which help the companies to engage their visitors, including potential and current customers (Gummerus et al., 2012). However, it is a difficult job for companies to get real picture and feedback of their loyal customers. Number of likes and comments are counted by the companies to evaluate their brand, which might not be an accurate picture because there can be many motives to like and comment on a brand pages, other than engaging with the brand. For example, a user can like or comment on a brand due many reasons, such as self -expression, because friends have liked same page, for chatting purposes, etc. Additionally, there are tons of meanings associated behind likes, including different degrees of liking, and whether people judge the value of likes based on their relationships to others; e.g. friends, acquaintances, or strangers who like the brand. The most liked brand page on Facebook up until December 2013 was Coca-Cola with 72 million likes, followed by Redbull with 40 million likes; but these likes were unable to translate sale figures, which remained same. Sales figures are effective key performance indicators. These indicators help brands to measure the performance of their brand page, including the number of people who see the brand page and updates as a form of return on investment (Li \& Bernoff 2011).

Online comments are one of the main constructs which shape social media. Facebook is one of the main social networking sites which allow its users to post new products, reviews about the products and rate those products Chen et al. (2011). Some new visitors visit a brand page to gain knowledge about that brand. Re- views and rating provide them comprehensive knowledge about that specific product. These reviews and rating by third party decrease the need of customer for advertising information (Yubo \& Jinhong, 2005). So rating and reviews provide effective information for customers (Füller et al., 2006). However, according to Tariq et al. (2012), most of the users in Pakistan are adults or underage and they use fake profiles on social network for enjoyment and upload inappropriate material on Facebook. These people with fake profiles like and comment a brand just for the sake of enjoyment; therefore, sometimes companies bear a big loss while making their decision about the brand. Information about the reviewer's identity has an effect on perceptions of members in particular community (Chris, Anindya, \& Batia, 2008). Reviews and rating provided by third party is the main issue because those reviews can be fake. So Evendors need to take action to get the information about the identities of the review generator (Chris et al., 2008) so that reviews and rating can be authenticated.

\section{Literature Review}

\subsection{Trust}

To reduce the uncertainty, companies need to build a trust of their products. Consumer trust is defined as "the expectation that a firm is dependable and will deliver on its promises" (Sirdeshmukh et al., 2002). Researchers argue that trust plays an important role to determine positive or negative effect on customer's perception. However, trust might be prejudiced by broader context, such as by designed features of website or by firm itself. There are many other factors which largely affect building of trust, such as frontline employees and the firm itself (Grayson et al., 2008). Trust plays a vital role in electronic market (Ba and Pavlou, 2002) and in the proposed model; trust plays a vital part as an independent construct. The present research investigates the limitations of the current literature and tries to develop a theoretical framework for the future of ecommerce and social commerce. The research explains a theoretical framework for social commerce drawing on social support theory, which in current study focused on forums and communities, ratings and reviews, recommendations and referrals.

Much more information is processed by the sellers about services and product as compared to buyers. In these situations, behavior can be explained by signaling theory. Signaling theory is development of economics (Spence, 1973), biology (Zahavi, 1975) and has been applied in information economics (Kirmani and Rao, 2000). Signaling theory explains that people heavily depend on signals if they need to evaluate a not so observable quality. Reliability of signals differs in nature. Assessment signals are highly consistent and 
specify the possession of a resource by wasting it (Donath, 2007). Researchers have found that people rely more on the reviews and rating of other people as compared to firm because reviews generated by other people are unbiased. Therefore, reviews and rating by other people are considered more trustworthy (Bickart and Schindler, 2001; Smith et al., 2005). Signaling theory explains the same concept; if other customer or consumer states the trustworthiness of a brand that signal is deemed more reliable as compared to the signal generated by company. In current study, three dimensions of trust will be tested, i.e. dispositional trust, interpersonal trust and organizational trust. Dispositional trust is defined as the general expectation that the "word, the promise, verbal, or written statement of another individual or group can be relied on"(Rotter, 1967, 1980).

Interpersonal trust, thus can be defined as a psychological state comprising the intention to accept vulnerability to the actions of another individual (a trustee), based upon the expectation that the other will perform a particular action that is important to the trustier (Lewis and Weigert, 1985; Mayer et al., 1995). Organizational trust is defined as the positive expectations individuals have about the competence, reliability and benevolence of organizational members, as well as the institutional trust within the organization (D Harrison McKnight, 2002; Mayer et al., 1995).

\subsection{Perceived risk and Perceived benefit}

Literature suggests that in various technologies there is a negative correlation between judgment of benefit and judgment of risk (Alhakami and Slovic, 1994; Frewer et al., 1998; Gregory and Mendelsohn, 1993). For the stated association, different researchers have provided explanations. For example, in terms of general attitude, people may judge different attitudes as favorable or unfavorable (Alhakami and Slovic, 1994). To decrease risk and increase benefit, people heavily rely on their beliefs, which are perceived favorable for adoption of technology. Researchers have assumed that perception of benefit and risks affects the favorableness of technology. Similarly, perceived risk and perceived benefit are said to have a relationship with each other. However, perception about risk can be changed by altering perception about benefit (Frewer et al., 1998). It is difficult for people to accept benefits linked to technology, which causes decrease in risk perception (Siegrist and Cvetkovich, 2000). Those people who trust institutions have less perceived risk and high perceived benefits. Different researchers have studied influence of trust on different variables, for example influence of trust on risk perception (Flynn et al., 1992), trust influences risk (Bord and O'Connor, 1992; Groothuis and Miller, 1997), relationship between trust and acceptance of technology (Bord and O'Connor, 1992) and trust influences perceived risk (Jungermann et al., 1996).
According to different scholars there are different views about the relationship of trust. Some stated that trust is an outcome of risk; some say that trust and risk are same, while others suggested that trust is a byproduct of risk. However, commonly trust and risk are treated as different concepts (Blau, 1964; Kee and Knox, 1970; Williamson, 1993); (Coleman \& Coleman, 1994). Trust is defined as a manifestation of a behavior by a person, which is based on his/her beliefs about the characteristics of another person (Mayer et al., 1995). On the basis of definition, a model was proposed by (Mayer et al., 1995) in which characteristics of both the trustor and trustee are included in dyadic trust of organizational relationship that influences the formation of trust. Trust of trustee's ability, integrity and benevolence are represented in the model, which included all three characteristics. The logic explained in this model is that the trustor will create trust or an intention to acceptance toward trustee if he/she finds trustee's ability, integrity and benevolence sufficient. There will be risk relationship with brand if the tustor's trust in brand will exceed the threshold of perceived risk. So an action in which perceived risk of negative outcome is involved, that action is highly dependable on trust (Luhmann, 1980). However, all types of risk taking behaviors are not dependent on trust.

\subsection{Online Reviews and Trust}

Researchers have examined the structure of different social networking sites, i.e. Fliker and Yahoo (Kumar et al., 2010). They concluded that there is an existence of isolated communities and users in both networks, but whole social network has expanded because of powerfully connected sections. Furthermore, trust is influenced by social support or social context (Weisberg et al., 2011).

Customers are more secure when there are social applications on an e-commerce platform and consequently customer's intentions to buy increases (Hajli, 2012). When companies welcome new visitors to join a page or social platform and support them positively, then they increase their ratings. With the help of these interactions trust of costumer increases and perception of risk decreases (Swamynathan et al., 2008). If the interaction on social network will be positive then user's trustworthiness will be high, while making a transaction (Swamynathan et al., 2008). Therefore, comments on Facebook will increase or decrease the trust of users.

\subsection{Relationship of Trust (IV) with Per- ceived Risk and Perceived Benefit (DV)}

Sjöberg (1998) inquired about perceived risk and its relationship with trust. He concluded that there is a weak relationship between perceived risk and trust on 
the basis of Swedish data. According to Sjoberg, there might be limitation to importance of trust. People normally act on that information which is incomplete and imperfect. Consequently consumer has to bear some risk while making a decision. Benefits are provided as an incentive to consumers by perceived benefit, which is beneficial for them while making decision (Wilkie and Pessemier, 1973).

By combining both perceived benefit and perceived risk, (Peter and Tarpey, 1975) presented an attractive framework. They assumed that products have both negative and positive attributes. Customer decides on the basis of net attributes (positive and negative) to purchase a product or not. The framework is same as Lewin (1943) and Bilkey (1953); Bilkey (1955) theories, which provide a theoretical framework for this study.

People who trust institutions have less perceived risk and high perceived benefits. Different researchers have studied influence of trust on different variables for example influence of trust on risk perception (Flynn et al., 1992; Jungermann et al., 1996) and trust influences risk (Bord and O'Connor, 1992; Groothuis and Miller, 1997), relationship between trust and acceptance of technology (Bord and O'Connor, 1990, 1992).

Perceived risk is a kind of subjective expectation loss (Pavlou, 2003; Peter and Ryan, 1976). If the result of individual behavior is not favorable and is opposite to subjective feelings, then perceived risk will be produced and is related to the extent of potential loss (Cunningham, 1967). Previous researchers figured out that trust reduces perceived risk and uncertainty (Kim et al., 2008; Pavlou, 2003). Trust, perceived risk and perceived benefit are closely related to each other. According to valance framework, perceived risk is an outcome of trust because trust minimizes the perceived risk and maximizes the perceived benefits (Mou and Cohen, 2014).

Based on the literature above, following hypotheses have been developed:

H1. Trust based on fake comments has a positive effect on perceived benefit.

H1a. Interpersonal trust based on fake comments has a positive effect on perceived benefit.

H1b. Dispositional trust based on fake comments has a positive effect on perceived benefit.

H1c. Institutional trust based on fake comments has a positive effect on perceived benefit.

H2. Trust based on fake comments has a negative effect on perceived risk.

H2a. Dispositional trust based on fake comments has a negative effect on perceived risk.
$H 2 b$. interpersonal trust based on fake comments has a negative effect on perceived risk.

H2c. Institutional trust based on fake comments has a negative effect on perceived risk.

H3. Trust based on original comments has a positive effect on perceived benefit.

H3a. Interpersonal trust based on original comments has a positive effect on perceived benefit.

H3b. Dispositional trust based on original comments has a positive effect on perceived benefit.

H3c. Institutional trust based on original comments has a positive effect on perceived benefit.

H4. Trust based on original comments has a negative effect on perceived risk.

H4a. Institutional trust based on original comments has a negative effect on perceived risk.

$H 4 b$. Dispositional trust based on original comments has a negative effect on perceived risk.

H4c. Institutional trust based on original comments has a negative effect on perceived risk.

\section{Theoretical Framework}

Online brand comments are trusted by different visitors of that brand page and they make decisions on the basis of those comments or reviews. Based on signalling theory (Bulbulia and Sosis, 2011), online reviews are signalling factors and third party endorsements that might be trusted by a person (Courtney \& Li, 2016). Most of previous researchers have taken online reviews as signals for readers, which were based on signalling theory (Eteokleous et al., 2016; Melo et al., 2016; Sparks et al., 2016). However, these signals are not useful unless the receiver considers them trustworthy (Mavlanov et al., 2016). Moreover, Valance theory (Murrell et al., 1970) explains the relationship between consumer behavior, perception of risk and benefit. Valance theory was originated from economics and psychology and later was used in marketing (Peter and Tarpey, 1975). On the basis of valance theory, researchers found that trust affects perceived risk and perceived benefit (Lin et al., 2014).

The model provides a view of the variables included in the project, their mutual relationships and the overall complexity of interconnections between research variables. In this research there are two models. First model contains the relationship between trust (Interpersonal 

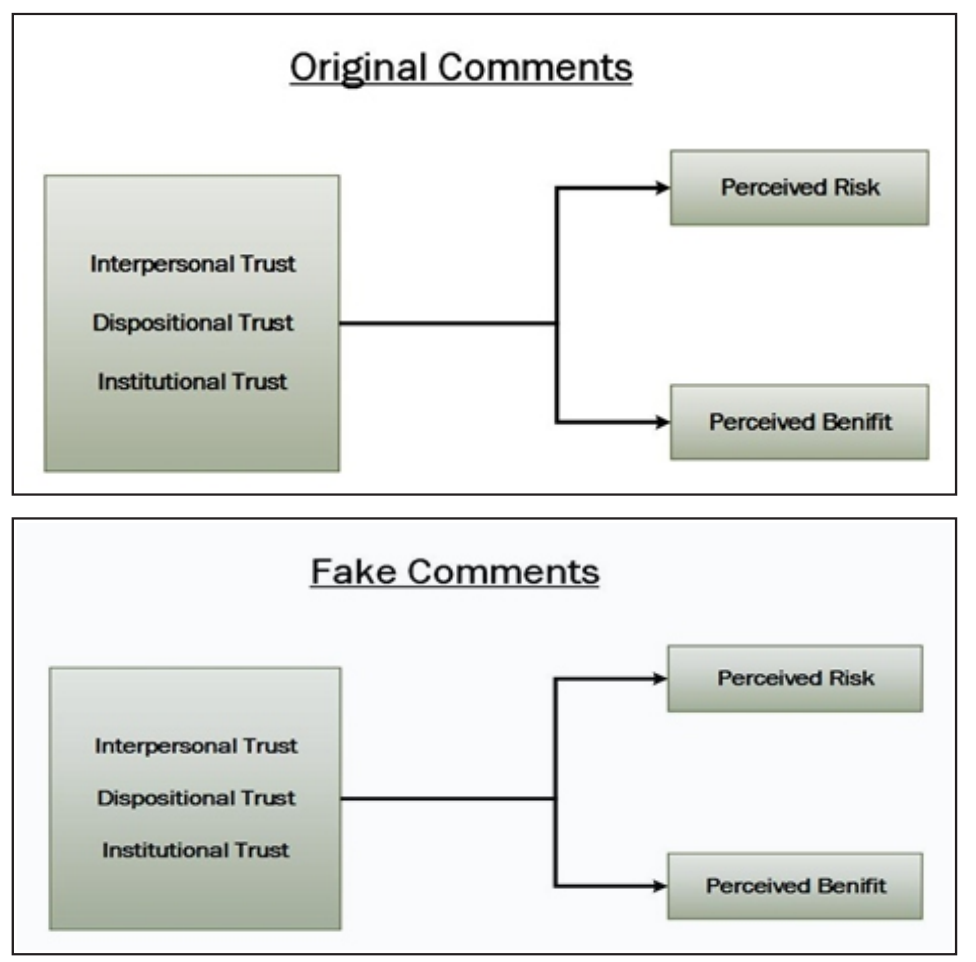

trust, dispositional trust and institutional trust), perceived risk and perceived benefit. This relationship is based on true comments provided by the participants. However, second model contains the relationship between trust (Interpersonal trust, dispositional trust and institutional trust), perceived risk and perceived benefit. This relationship is based on Fake comments provided by the participants.

\section{Methodology}

\subsection{Experiment procedure}

It is almost impossible to figure out fake comments from Facebook pages. So an experiment was generated to test the hypothesis. In previous studies, experiments were conducted to check online behavior of customers (Tsai et al., 2011). In the current study, a page of Facebook was created containing two mostly used brands among males and females i.e. Shalwar Kameez for female and Kurta Shalwar for males. The products were related to same brand. Both genders were invited to join the page. Page administrator created five seed comments then participants were asked to comment on the brand of their own choice. Comments were distributed in two parts; fake and original on the basis of profile, for example, if a female comments on male focused products that comment was considered as a fake comment, etc. Furthermore, interviews were conducted after experiment to measure the existence of fake identities.
During the interview participants were asked different questions about their Facebook accounts; such as, "Is he or she using more than one Facebook accounts?" "For what purpose does a person usually visit the brand page?"

\subsection{Study Population}

University students make up the largest segment of the SNS user population, with $75 \%$ of online adults using SNS (Ellison et al., 2007; Lenhart, 2009). Additionally, males and females age 18 and older are equally likely to use SNSs, with the majority of users having two or more different SNS profile (Lenhart, 2009; Lenhart et al., 2010). Students are said to be demanding consumer population that facilitates the acceptance of social media in an era of consumer control (Mangold and Faulds, 2009). Thus, the use of student sample in this study was deemed appropriate.

Students from two universities including males (from International Islamic University) and females (from Fatima Jinnah University) were taken as sample of current study. 117 female students and 216 male students participated in experiments. 35 percent of total sample was represented by females and 65 percent of sample was represented by males in experiment.

\subsection{Research tools}

Mix strategy was used for collection of data. Questionnaires were distributed among the participants. 
Questionnaire contained four items of perceived benefit Adapted from Porter and Donthu (2006), four items of institutional trust were adapted by D Harrison McKnight (2002). Five items scale of dispositional trust and three items scale of interpersonal trust were adapted from the instruments used by Kim et al. (2008), (Walczuch and Lundgren (2004)), Koufaris and HamptonSosa (2004) and Jarvenpaa et al. (2000). A four items scale of perceived risk developed by Swaminathan et al. (1999) was used to collect the data.

Data were distributed in two parts based on fake and original comments. Regression was applied to test the model on both sets of data. Impact of trust including dispositional trust, interpersonal trust and institutional trust (independent variables) will be tested on perceived risk and perceived benefit (dependent variables). (Weston, 2001).

\subsection{Pilot study}

A Facebook page was created containing two products of same brand. One of the items was female specific, i.e. shalwar kameez and second item was male specific, i.e. Kurta Shalwar. Five seed comments on each product were created by the administrator of page .Thirty participants including fifteen male and fifteen females were asked to comment on brand page. To test trust, perceived risk and perceived benefit questionnaires were distributed among the participants. Afterwards interviews were conducted from the participants including following questions.

- Is he/she using more than one Facebook account?

- For what purpose does a person visit brand page? (chatting, information gathering, self-expression)

As per the results of reliability analysis, Chronbach's Alpha for Institutional Trust and Dispositional Trust were 0.708 and 0.719 , respectively. Whereas, reliability of Interpersonal Trust was 0.781 , for perceived benefit 0.810; similarly, cronbach's alpha for Perceived Risk was 0.795 .

\section{Results}

\subsection{Regression Analysis}

\subsubsection{Trust and perceived benefit on the basis of fake comments}

For the sample of Fake comments regression was run to check the effect of trust (Interpersonal trust, dispositional trust and institutional trust) on perceived benefit. The effects of interpersonal trust have been analyzed on perceived benefits. Results show that R-square $=.001$; Adj. R Square $=-.005$. The value of $\mathrm{R}$ Square
(.001) shows that approximately $1 \%$ variation in perceived benefits was due to interpersonal trust. The Fvalue is .209. Results revealed a non-significant effect of interpersonal trust $(\beta=0.038)$ on perceived benefits.

The effect of dispositional trust has been analyzed on perceived benefits. Result depicted in Table 1. The result shows that R-square $=.092 ;$ Adj. $\mathrm{R}$ Square $=.086$. The value of $\mathrm{R}$ Square (.092) shows that approximately $9 \%$ variation in perceived benefits was due to dispositional trust. The F-value is 14.86. Results revealed a positively significant effect of dispositional trust $(\beta=$ $\left.0.303^{* *}\right)$ on perceived benefits.

The effect of institutional trust has been analyzed on perceived benefits. Result depicted in Table 1. The result shows that R-square $=.153$; Adj. R Square $=.148$. The value of $\mathrm{R}$ Square (.153) shows that approximately $15 \%$ variation in perceived benefits was due to institutional trust. The F-value is 26.62. Results revealed a positively significant effect of institutional trust $\left(\beta=0.39^{* *}\right)$ on perceived benefits.

\subsection{Trust and perceived risk on the basis of fake comments}

For the sample of Fake comments regression was run to check the effect of trust (interpersonal trust, dispositional trust and institutional trust) on perceived risk.

The effect of interpersonal trust has been analyzed on perceived risk. Result depicted in Table 2. The result shows that R-square $=.031$; Adj. R Square $=0.024$. The value of $R$ Square (.031) shows that approximately $3 \%$ variation in perceived risk was due to interpersonal trust. The F-value is 4.65 . Results revealed a positively significant effect of interpersonal trust $\left(\beta=0.17^{* *}\right)$ on perceived risk.

Similarly, the effect of dispositional trust has been analyzed on perceived risk. The results indicate that R-square $=.002$; Adj. R Square $=-.005$. The value of $\mathrm{R}$ Square (.002) shows that approximately $2 \%$ variation in perceived risk was due to dispositional trust. The Fvalue is .224. Results revealed an insignificant effect of dispositional trust $(\beta=0 .-.041)$ on perceived risk.

Moreover, the effect of institutional trust has been analyzed on perceived benefits. The results in table (2) show that R-square $=.000$; Adj. R Square $=-.007$. The value of $\mathrm{R}$ Square (.000) shows that approximately $00 \%$ variations in perceived risk are due to institutional trust. The F-value is .006. Results revealed an insignificant effect of institutional trust $(\beta=-.006)$ on perceived risk.

\subsection{Trust and perceived benefit on the basis of original comments}

For the sample of original comments regression was run to check the effect of trust (interpersonal trust, dis- 
Table 1: Regression Analysis for Trust \& Perceived Benefit (Fake Comments)

\begin{tabular}{|c|c|c|c|c|c|c|c|c|}
\hline $\begin{array}{l}\text { Independent } \\
\text { Variable }\end{array}$ & $\begin{array}{c}\text { Dependent } \\
\text { Variable }\end{array}$ & $\mathrm{R}$ & R Square & $\begin{array}{l}\text { Adjusted } \\
\text { R Square }\end{array}$ & $\mathrm{F}$ & $\begin{array}{l}\text { Significance } \\
\text { of ANOVA }\end{array}$ & Beta & $\begin{array}{c}\text { Significance of } \\
\text { Coefficients }\end{array}$ \\
\hline $\begin{array}{l}\text { Interpersonal } \\
\text { Trust }\end{array}$ & $\begin{array}{l}\text { Received } \\
\text { benefits }\end{array}$ & 0.38 & 0.001 & -0.005 & 0.209 & 0.648 & 0.38 & 0.648 \\
\hline $\begin{array}{l}\text { Dispositional } \\
\text { Trust }\end{array}$ & $\begin{array}{l}\text { Received } \\
\text { benefits }\end{array}$ & 0.303 & 0.092 & 0.086 & 14.862 & 0.000 & 0.303 & 0.000 \\
\hline $\begin{array}{l}\text { Institutional } \\
\text { Trust }\end{array}$ & $\begin{array}{l}\text { Received } \\
\text { benefits }\end{array}$ & 0.392 & 0.153 & 0.148 & 26.622 & 0.000 & 0.392 & 0.000 \\
\hline
\end{tabular}

Table 2: Regression Analysis for Trust \& Perceived Risk (Fake Comments)

\begin{tabular}{|c|c|c|c|c|c|c|c|c|}
\hline $\begin{array}{l}\text { Independent } \\
\text { Variable }\end{array}$ & $\begin{array}{c}\text { Dependent } \\
\text { Variable }\end{array}$ & $\mathrm{R}$ & R Square & $\begin{array}{l}\text { Adjusted } \\
\text { R Square }\end{array}$ & F & $\begin{array}{l}\text { Significance } \\
\text { of ANOVA }\end{array}$ & Beta & $\begin{array}{c}\text { Significance of } \\
\text { Coefficients }\end{array}$ \\
\hline Interpersonal & Received & 0.175 & 0.031 & 0.024 & 4.655 & 0.033 & 0.175 & 0.033 \\
\hline Trust & Risk & & & & & & & \\
\hline Dispositional & Received & 0.041 & 0.002 & -0.005 & 0.224 & 0.662 & -0.041 & 0.662 \\
\hline Trust & Risk & & & & & & & \\
\hline Institutional & Received & 0.006 & 0 & -0.007 & 0.006 & 0.938 & -0.006 & 0.938 \\
\hline Trust & Risk & & & & & & & \\
\hline
\end{tabular}

positional trust and institutional trust) on perceived benefit.

The effects of interpersonal trust have been analyzed on perceived benefits. Result shows that R-square $=.147$; Adj. $\mathrm{R}$ Square = .142. The value of $\mathrm{R}$ Square (.147) shows that approximately $15 \%$ variation in perceived benefits was due to interpersonal trust. The F-value is 31.272. Results revealed positive significant effect of interpersonal trust $\left(\beta=0.383^{* *}\right)$ on perceived benefits.

The effect of dispositional trust has been analyzed on perceived benefits. Result depicted in Table 3. The result shows that R-square $=.068$; Adj. $\mathrm{R}$ Square $=.062$. The value of $R$ Square (.068) shows that approximately $7 \%$ variation in perceived benefits was due to dispositional trust. The F-value is 13.19. Results revealed a negatively significant effect of dispositional trust $(\beta=$ $-0.260^{* *}$ ) on perceived benefits.

The effect of institutional trust has been analyzed on perceived benefits. Result depicted in Table 3. The result shows that R-square $=.019 ;$ Adj. $\mathrm{R}$ Square $=.013$. The value of $\mathrm{R}$ Square (.019) shows that approximately $2 \%$ variation in perceived benefits was due to institutional trust. The F-value is 3.498. Results revealed an insignificant effect of institutional trust $(\beta=0.137)$ on perceived benefits.

\subsection{Trust and perceived risk on the basis of original comments}

For the sample of original comments regression was run to check the effect of trust (interpersonal trust, dispositional trust and institutional trust) on perceived risk.

The effect of interpersonal trust has been analyzed on perceived risk. Result depicted in Table 6. The result shows that R-square $=.032$; Adj. R Square $=0.026$. The value of $\mathrm{R}$ Square (.032) shows that approximately $3 \%$ variation in perceived risk was due to interpersonal trust. The F-value is 5.951. Results revealed a negatively significant effect of interpersonal trust $\left(\beta=-0.178^{* *}\right)$ on 
Table 3: Regression Analysis for Trust \& Perceived Benefit (Original Comments)

\begin{tabular}{|c|c|c|c|c|c|c|c|c|}
\hline $\begin{array}{l}\text { Independent } \\
\text { Variable }\end{array}$ & $\begin{array}{c}\text { Dependent } \\
\text { Variable }\end{array}$ & $\mathrm{R}$ & R Square & $\begin{array}{l}\text { Adjusted } \\
\text { R Square }\end{array}$ & F & $\begin{array}{l}\text { Significance } \\
\text { of ANOVA }\end{array}$ & Beta & $\begin{array}{c}\text { Significance of } \\
\text { Coefficients }\end{array}$ \\
\hline $\begin{array}{l}\text { Interpersonal } \\
\text { Trust }\end{array}$ & $\begin{array}{c}\text { Received } \\
\text { benefit }\end{array}$ & 0.383 & 0.147 & 0.142 & 31.272 & 0.000 & 0.383 & 0.000 \\
\hline $\begin{array}{l}\text { Dispositional } \\
\text { Trust }\end{array}$ & $\begin{array}{c}\text { Received } \\
\text { benefit }\end{array}$ & 0.026 & 0.068 & 0.062 & 13.199 & 0.000 & -0.026 & 0.000 \\
\hline $\begin{array}{l}\text { Institutional } \\
\text { Trust }\end{array}$ & $\begin{array}{c}\text { Received } \\
\text { benefit }\end{array}$ & 0.137 & 0.019 & 0.013 & 3.498 & 0.063 & 0.137 & 0.063 \\
\hline
\end{tabular}

Table 4: Regression Analysis for Trust \& Perceived Risk (Original Comments)

\begin{tabular}{|c|c|c|c|c|c|c|c|c|}
\hline $\begin{array}{l}\text { Independent } \\
\text { Variable }\end{array}$ & $\begin{array}{c}\text { Dependent } \\
\text { Variable }\end{array}$ & $\mathrm{R}$ & R Square & $\begin{array}{l}\text { Adjusted } \\
\text { R Square }\end{array}$ & $\mathrm{F}$ & $\begin{array}{l}\text { Significance } \\
\text { of ANOVA }\end{array}$ & Beta & $\begin{array}{c}\text { Significance of } \\
\text { Coefficients }\end{array}$ \\
\hline Interpersonal & Received & 0.178 & 0.032 & 0.026 & 5.951 & 0.016 & 0.178 & 0.016 \\
\hline Trust & Risk & & & & & & & \\
\hline Dispositional & Received & 0.502 & 0.252 & 0.248 & 61.392 & 0.000 & 0.502 & 0.000 \\
\hline Trust & Risk & & & & & & & \\
\hline Institutional & Received & 0.441 & 0.195 & 0.19 & 44.04 & 0.000 & 0.441 & 0.000 \\
\hline Trust & Risk & & & & & & & \\
\hline
\end{tabular}

perceived risk.

The effect of dispositional trust has been analyzed on perceived risk. Result depicted in Table 4. The result shows that R-square $=.252$; Adj. R Square $=.248$. The value of $\mathrm{R}$ Square (.252) shows that approximately $25 \%$ variation in perceived risk was due to dispositional trust. The F-value is 61.392 . Results revealed positively significant effect of dispositional trust $\left(\beta=0.502^{* *}\right)$ on perceived risk.

The effect of institutional trust has been analyzed on perceived benefits. Result depicted in Table 4. The result shows that R-square $=.195$; Adj. R Square $=.190$. The value of R Square (.195) shows that approximately $19 \%$ variations in perceived risk were due to institutional trust. The F-value is 44.040. Results revealed a positively significant effect of institutional trust $\left(\beta=0.441^{* *}\right)$ on perceived benefits.

\section{Discussion}

The results of study were valuable for determining the effect of trust (interpersonal trust, dispositional trust and institutional trust) on perceived risk and perceived benefit. Effect of trust (based on fake IDs) was checked on Perceived risk and perceived benefit. Results show that interpersonal trust does not affect perceived risk or perceived benefits. Similarly, Institutional trust and dispositional trust do not affect perceived risk. However, perceived benefit is positively affected by both institutional and dispositional trust. So $\mathrm{H} 1 \mathrm{~b}$ and $\mathrm{H} 1 \mathrm{c}$ are accepted on the basis of results.

Effects of trust (based on original IDs) was also checked on perceived risk and perceived benefit. Result shows that interpersonal trust positively affects perceived benefit; however, perceived risk is not affected by interpersonal trust, therefore, $\mathrm{H} 3 \mathrm{a}$ is accepted. Institutional trust does not affect perceived benefit. However, 
perceived risk is positively affected by institutional trust so alternative hypothesis of $\mathrm{H} 4 \mathrm{a}$ is accepted. There is a positive effect of dispositional trust on perceived benefit and negative effect on perceived risk leading to the acceptance of $\mathrm{H} 3 \mathrm{~b}$ and $\mathrm{H} 4 \mathrm{~b}$.

Researchers have concluded that reviews and rating on a product by third party plays an important role for the customers to gain information about that particular product. These reviews and rating by third party have decreased the need of customer for gaining information through advertising (Chen and Xie, 2005). Furthermore, brand engagement empowers customers to learn about other products where rating and online reviews are very helpful for them Prahalad and Ramaswamy (2004). So rating and reviews provide effective information for customers (Fuller et al., 2009). Approximately, $83 \%$ of Fortune 500 companies use some form of social media to connect and engage with consumers in the marketplace (Naylor et al., 2012). The findings of this study are in line with literature that interpersonal trust has a positive effect on perceived benefit. People heavily rely on reviews and rating of other people while collecting information about a particular product (Malbon, 2013). Furthermore, while having a look on comments it can be observed that if the seed comments are negative then most of comment by other users are negative and vice versa. Therefore, perceived risk of users may increase due to trend of negative comments.

However, many companies use "Push" approach, which creates a negative attitude of company towards social media. Companies need to use different strategies while communicating with customers through social media such as get multidirectional and more conversational. Companies use traditional marketing and advertising approaches which effect the trust of users about what companies are telling them (Gil, 2010). Furthermore, users believe more in third party comments than information provided by companies (Nelson-Field et al., 2012). In another survey that was done by the Kelsey Group (comScore / The Kelsey Group, October 2007) "review users noted that reviews generated by fellow consumers had a greater influence than those generated by professionals". So in online social networks concept of influencers is getting more attraction. A person is no longer influenced by "expert" but also by other influencers such as attractive comments, large network etc. The results of current study are in line with previous research that users perceived risk increases while trusting in institution because of push strategy and traditional advertisement. However, their perceived benefit increases while having conversation with other users, because people believe more in third party comments than information provided by companies.

Researchers have found that in Pakistani culture, risk attitude and perception plays an important role in shaping decision. Generally, tendency of risk aversion is involved while taking decision (Iqbal et al., 2016). Fur- thermore, effect of internet trust on risk perception and consumer attitude towards internet is positive. Propensity to trust is a determinant not only for interpersonal relationships but also for trust in technological systems (Grabner-Krauter, 2008). Hence, perceived risk of users may increase because of low trust in technological system (i.e. facebook). According to Antony and Lin (2006), online decisions are affected by perceived risk. Furthermore, people were not ready to take any type of opportunity that involves any type of risk (Ellis, 2000). However, in current study dispositional trust of users was tested in context of Facebook as well as brand. Perceived risk of users may increase because of push strategy by companies. Users of social media do not trust in information provided by companies. However, people trust more on the comments provided by their friends or third party with larger network as compared to information provided by company itself (Gil, 2010).

Studies have concluded that fake reviews can mislead users and do not provide an accurate picture of the product (Tsaparas, Ntoulas \& Terzi, 2011; Lappas and Gunopulos, 2010). Furthermore, fake reviews mislead readers by writing fake positive or negative opinions to promote or damage reputation (MacDonald, Ounis \& Soboroff, 2007; Liu, 2010). So on the basis of fake reviews, a visitor of page may be trusting on negative comments provided by fake ID and that negative comment can increase the risk of visitor. So trust can positively or negatively affect perceived risk or perceived benefit. However, in current study dispositional trust positively affects perceived benefits.

\section{Conclusion}

According to current study people believe more in comments and information provided by their friends or by third party. While getting information from social media users trust in comments and reviews provided by other users without differentiating original and fake comments. Users of Facebook trust in brand but normally ignore information provided by the company itself.

Companies make decisions on the basis of number of likes and shares. However, comments and reviews are being ignored by companies. Comments and reviews play a vital role as feedback for companies. Furthermore, other users of social networking sites are affected by comments and reviews. There are many users of social networking sites, which join social media with fake IDs and post negative comments and reviews just for the enjoyment which effects trust of other people. Results of current study show that perceived benefit and risk of user is affected by interpersonal trust. So those fake comments affect trust of other users. 


\subsection{Implications}

Current study will be helpful for managers to make important decisions and increase brand engagement. Furthermore, companies should not go for traditional advertisement while advertising on social media. Study will help companies to communicate with their customers more effectively by viewing comments.

\subsection{Limitations and future directions}

Due to lake of time and resources data were collected from students of two universities. Future research can be conducted by maximizing data including different age groups and professions. A very interesting trend was observed in comments that if the seed comments are positive then most of the following comments by other users are also positive and vice versa. Future research can be conducted on psychology of users towards a brand or a service in social media based on seed comments or comments that are initially viewed by the user.

Due to non-availability of funds current study was conducted based on data collected from universities in Pakistan. However future studies can be conducted for comparison of consumer behavior from different countries.

\section{References}

Alhakami, A. S. and Slovic, P. (1994). A psychological study of the inverse relationship between perceived risk and perceived benefit. Risk analysis, 14(6):1085-1096.

Anderson, E. W. (1998). Customer satisfaction and word of mouth. Journal of service research, 1(1):5-17.

Ba, S. and Pavlou, P. A. (2002). Evidence of the effect of trust building technology in electronic markets: Price premiums and buyer behavior. MIS quarterly, pages 243-268.

Ba, S., Whinston, A. B., and Zhang, H. (1999). Building trust in the electronic market through an economic incentive mechanism. In Proceedings of the 20th international conference on Information Systems, pages 208-213. Association for Information Systems.

Back, M. D., Stopfer, J. M., Vazire, S., Gaddis, S., Schmukle, S. C., Egloff, B., and Gosling, S. D. (2010). Facebook profiles reflect actual personality, not self-idealization. Psychological science, 21(3):372-374.

Bickart, B. and Schindler, R. M. (2001). Internet forums as influential sources of consumer information. Journal of interactive marketing, 15(3):31-40.

Bilkey, W. J. (1953). A psychological approach to consumer behavior analysis. Journal of Marketing, 18(1):18-25.
Bilkey, W. J. (1955). Psychic tensions and purchasing behavior. The Journal of Social Psychology, 41(2):247-257.

Blau, P. M. (1964). Exchange and power in social life. Transaction Publishers.

Bord, R. J. and O'Connor, R. E. (1990). Determinants of risk perceptions of a hazardous waste site. Risk analysis, 12(3):411-416.

Bord, R. J. and O'Connor, R. E. (1992). Determinants of risk perceptions of a hazardous waste site. Risk analysis, 12(3):411-416.

Bulbulia, J. and Sosis, R. (2011). Signalling theory and the evolution of religious cooperation. Religion, 41(3):363-388.

Castelfranchi, C. (2003). Grounding we-intentions in individual social attitudes. In Realism in action, pages 195-212. Springer.

Chauhan, K., Saji, K., and Pillai, A. (2013). Role of content strategy in social media brand communities: a case of higher education institutes in india. Journal of Product $\mathcal{E}$ Brand Management, 22(1):40-51.

Chen, J., Xu, H., and Whinston, A. B. (2011). Moderated online communities and quality of user-generated content. Journal of Management Information Systems, 28(2):237-268.

Chen, Y. and Xie, J. (2005). Third-party product review and firm marketing strategy. Marketing Science, 24(2):218-240.

Coppola, N. W., Hiltz, S. R., and Rotter, N. G. (2004). Building trust in virtual teams. IEEE transactions on professional communication, 47(2):95-104.

D Harrison McKnight, N. L. C. (2002). What trust means in e-commerce customer relationships: An interdisciplinary conceptual typology. International journal of electronic commerce, 6(2):35-59.

Donath, J. (2007). Signals in social supernets. Journal of Computer-Mediated Communication, 13(1):231-251.

Ellison, N. B., Steinfield, C., and Lampe, C. (2007). The benefits of facebook friends: social capital and college students use of online social network sites. Journal of Computer-Mediated Communication, 12(4):1143-1168.

Eteokleous, P. P., Katsikeas, C. S., and Leonidou, L. C. (2016). Review of research on csr in international marketing: 19932013. In Lets Get Engaged! Crossing the Threshold of Marketings Engagement Era, pages 683-684. Springer.

Flynn, J., Burns, W., Mertz, C., and Slovic, P. (1992). Trust as a determinant of opposition to a high-level radioactive waste repository: Analysis of a structural model. Risk analysis, 12(3):417-429.

Frewer, L. J., Howard, C., and Shepherd, R. (1998). Understanding public attitudes to technology. Journal of Risk Research, 1(3):221-235.

Füller, J., Bartl, M., Ernst, H., and Mühlbacher, H. (2006). Community based innovation: How to integrate members of virtual communities into new product development. Electronic Commerce Research, 6(1):57-73. 
Gefen, D., Straub, D. W., and Rigdon, E. E. (2011). An update and extension to sem guidelines for admnistrative and social science research. Management Information Systems Quarterly, 35(2):iii-xiv.

Grayson, K., Johnson, D., and Chen, D.-F. R. (2008). Is firm trust essential in a trusted environment? how trust in the business context influences customers. Journal of Marketing Research, 45(2):241-256.

Gregory, R. and Mendelsohn, R. (1993). Perceived risk, dread, and benefits. Risk Analysis, 13(3):259-264.

Groothuis, P. A. and Miller, G. (1997). The role of social distrust in risk-benefit analysis: A study of the siting of a hazardous waste disposal facility. Journal of Risk and Uncertainty, 15(3):241-257.

Gummerus, K. S., Coulter, J., Liljander, V., Weman, E., and Pihlström, M. (2012). Customer engagement in a facebook brand community. Management Research Review, 35(9):857877.

Hajli, M. (2012). An integrated model for e-commerce adoption at the customer level with the impact of social commerce. International Journal of Information Science and Management.

Hajli, N. (2015). Social commerce constructs and consumer's intention to buy. International Journal of Information Management, 35(2):183-191.

Hoffman, D. L. and Fodor, M. (2010). Can you measure the roi of your social media marketing? MIT Sloan Management Review, 52(1):41.

Ivanov, M. and Ganev, G. (2014). Bulgarian business elite, 1900s-2000s. The Power of Corporate Networks: A Comparative and Historical Perspective, 26:213.

Jarvenpaa, S. L., Tractinsky, N., and Saarinen, L. (1999). Consumer trust in an internet store: a cross-cultural validation. Journal of Computer-Mediated Communication, 5(2):0-0.

Jungermann, H., Pfister, H.-R., and Fischer, K. (1996). Credibility, information preferences, and information interests. Risk Analysis, 16(2):251-261.

Kee, H. W. and Knox, R. E. (1970). Conceptual and methodological considerations in the study of trust and suspicion. Journal of conflict resolution, 14(3):357-366.

Kim, D. J., Ferrin, D. L., and Rao, H. R. (2008). A trust-based consumer decision-making model in electronic commerce: The role of trust, perceived risk, and their antecedents. Decision support systems, 44(2):544-564.

Kirmani, A. and Rao, A. R. (2000). No pain, no gain: A critical review of the literature on signaling unobservable product quality. Journal of marketing, 64(2):66-79.

Koufaris, M. and Hampton-Sosa, W. (2004). The development of initial trust in an online company by new customers. Information $\mathcal{E}$ management, 41(3):377-397.
Kumar, R., Novak, J., and Tomkins, A. (2010). Structure and evolution of online social networks. In Link mining: models, algorithms, and applications, pages 337-357. Springer.

Lappas, T., Sabnis, G., and Valkanas, G. (2016). The impact of fake reviews on online visibility: A vulnerability assessment of the hotel industry. Information Systems Research, 27(4):940-961.

Lee, M. K. and Turban, E. (2001). A trust model for consumer internet shopping. International Journal of electronic commerce, 6(1):75-91.

Lenhart, A. (2009). Teens and sexting. Pew internet $\mathcal{E}$ American life project, 1:1-26.

Lenhart, A., Ling, R., Campbell, S., and Purcell, K. (2010). Teens and mobile phones: Text messaging explodes as teens embrace it as the centerpiece of their communication strategies with friends. Pew Internet $\mathcal{E}$ American Life Project.

Lewin, K. (1943). Forces behind food habits and methods of change. Bulletin of the national Research Council, 108(1043):35-65.

Lewis, J. D. and Weigert, A. (1985). Trust as a social reality. Social forces, 63(4):967-985.

Liang, T.-P. and Turban, E. (2011). Introduction to the special issue social commerce: a research framework for social commerce. International Journal of electronic commerce, 16(2):5-14.

Lin, J., Wang, B., Wang, N., and Lu, Y. (2014). Understanding the evolution of consumer trust in mobile commerce: a longitudinal study. Information Technology and Management, 15(1):37-49.

Lin, K.-Y. and Lu, H.-P. (2011). Why people use social networking sites: An empirical study integrating network externalities and motivation theory. Computers in Human Behavior, 27(3):1152-1161.

Liu, B. (2013). Opinion spam detection: Detecting fake reviews and reviewers.

Luhmann, N. (1980). Trust: A mechanism for the reduction of social complexity, trust and power.

Malbon, J. (2013). Online cross-border consumer transactions: A proposal for developing fair standard form contract terms. Browser Download This Paper.

Malhotra, A., Malhotra, C. K., and See, A. (2013). How to create brand engagement on facebook. MIT Sloan Management Review, 54(2):18.

Mangold, W. G. and Faulds, D. J. (2009). Social media: The new hybrid element of the promotion mix. Business horizons, 52(4):357-365.

Mayer, R. C., Davis, J. H., and Schoorman, F. D. (1995). An integrative model of organizational trust. Academy of management review, 20(3):709-734. 
Melo, A. J., Hernández-Maestro, R. M., and Muñoz-Gallego, P. A. (2016). Service quality perceptions, online visibility, and business performance in rural lodging establishments. Journal of Travel Research, page 0047287516635822.

Mou, J. and Cohen, J. (2014). Trust, risk barriers and health beliefs in consumer acceptance of online health services.

Mukherjee, A., Liu, B., and Glance, N. (2012). Spotting fake reviewer groups in consumer reviews. In Proceedings of the 21st international conference on World Wide Web, pages 191200. ACM.

Murrell, J. N., Kettle, S. F. A., and Tedder, J. M. (1970). Valence theory.

Nelson-Field, K., Riebe, E., and Sharp, B. (2012). What's not to like?. Journal of Advertising Research, 52(2):262-269.

Nooteboom, B., Berger, H., and Noorderhaven, N. G. (1997). Effects of trust and governance on relational risk. Academy of management Journal, 40(2):308-338.

Pavlou, P. A. (2003). Consumer acceptance of electronic commerce: Integrating trust and risk with the technology acceptance model. International journal of electronic commerce, 7(3):101-134.

Peter, J. P. and Ryan, M. J. (1976). An investigation of perceived risk at the brand level. Journal of marketing research, pages $184-188$.

Peter, J. P. and Tarpey, L. X. (1975). A comparative analysis of three consumer decision strategies. Journal of consumer research, 2(1):29-37.

Phua, J. and Ahn, S. J. G. (2014). Explicating the" like" on facebook brand pages: The effect of intensity of facebook use, number of overall" likes", and number of friends'" likes" on consumers'perceived brand outcomes. In American Academy of Advertising. Conference. Proceedings (Online), page 150. American Academy of Advertising.

Prahalad, C. K. and Ramaswamy, V. (2004). Co-creating unique value with customers. Strategy E leadership, 32(3):49.

Qureshi, I. A. and Mir, I. A. (2013). Users perceptions, attitudes and continuance intentions of facebook: Insights from pakistan.

Racherla, P., Mandviwalla, M., and Connolly, D. J. (2012). Factors affecting consumers' trust in online product reviews. Journal of Consumer Behaviour, 11(2):94-104.

Richins, M. L. (1984). Word of mouth communication as negative information. NA-Advances in Consumer Research Volume 11.

Rotter, J. B. (1967). A new scale for the measurement of interpersonal trust. Journal of personality, 35(4):651-665.

Rotter, J. B. (1980). Interpersonal trust, trustworthiness, and gullibility. American psychologist, 35(1):1.
Sako, M. and Helper, S. (1998). Determinants of trust in supplier relations: Evidence from the automotive industry in japan and the united states. Journal of Economic Behavior $\mathcal{E}$ Organization, 34(3):387-417.

Sashi, C. (2012). Customer engagement, buyer-seller relationships, and social media. Management decision, 50(2):253-272.

Schau, H. J. and Gilly, M. C. (2003). We are what we post? self-presentation in personal web space. Journal of consumer research, 30(3):385-404.

Siegrist, M. and Cvetkovich, G. (2000). Perception of hazards: The role of social trust and knowledge. Risk analysis, 20(5):713-720.

Sirdeshmukh, D., Singh, J., and Sabol, B. (2002). Consumer trust, value, and loyalty in relational exchanges. Journal of marketing, 66(1):15-37.

Sjöberg, L. (1998). Risk perception: Experts and the public. European Psychologist, 3(1):1-12.

Smith, D., Menon, S., and Sivakumar, K. (2005). Online peer and editorial recommendations, trust, and choice in virtual markets. Journal of interactive marketing, 19(3):15-37.

Smock, A. D., Ellison, N. B., Lampe, C., and Wohn, D. Y. (2011). Facebook as a toolkit: A uses and gratification approach to unbundling feature use. Computers in Human Behavior, 27(6):2322-2329.

Sparks, B. A. and Browning, V. (2011). The impact of online reviews on hotel booking intentions and perception of trust. Tourism Management, 32(6):1310-1323.

Sparks, B. A., Perkins, H. E., and Buckley, R. (2013). Online travel reviews as persuasive communication: The effects of content type, source, and certification logos on consumer behavior. Tourism Management, 39:1-9.

Sparks, B. A., So, K. K. F., and Bradley, G. L. (2016). Responding to negative online reviews: The effects of hotel responses on customer inferences of trust and concern. Tourism Management, 53:74-85.

Swaminathan, V., Lepkowska-White, E., and Rao, B. P. (1999). Browsers or buyers in cyberspace? an investigation of factors influencing electronic exchange. Journal of ComputerMediated Communication, 5(2):0-0.

Swamynathan, G., Wilson, C., Boe, B., Almeroth, K., and Zhao, B. Y. (2008). Do social networks improve e-commerce?: a study on social marketplaces. In Proceedings of the first workshop on Online social networks, pages 1-6. ACM.

Tan, Y.-H. and Thoen, W. (2000). A logical model of trust in electronic commerce. Electronic Markets, 10(4):258-263.

Tariq, W., Mehboob, M., Asf, M., and Khan, Y. (2012). The impact of social media and social networks on education and students of pakistan.

Tosun, L. P. (2012). Motives for facebook use and expressing true self on the internet. Computers in Human Behavior, 28(4):1510-1517. 
Tsai, J. Y., Egelman, S., Cranor, L., and Acquisti, A. (2011). The effect of online privacy information on purchasing behavior: An experimental study. Information Systems Research, 22(2):254-268.

Utz, S., Kerkhof, P., and van den Bos, J. (2012). Consumers rule: How consumer reviews influence perceived trustworthiness of online stores. Electronic Commerce Research and Applications, 11(1):49-58.

Van Doorn, J., Lemon, K. N., Mittal, V., Nass, S., Pick, D. Pirner, P., and Verhoef, P. C. (2010). Customer engagement behavior: Theoretical foundations and research directions. Journal of Service Research, 13(3):253-266.

Wang, Z., Tchernev, J. M., and Solloway, T. (2012). A dynamic longitudinal examination of social media use, needs, and gratifications among college students. Computers in Human Behavior, 28(5):1829-1839.

Weisberg, J., Te'eni, D., and Arman, L. (2011). Past purchase and intention to purchase in e-commerce: The mediation of social presence and trust. Internet research, 21(1):82-96.

Wilkie, W. L. and Pessemier, E. A. (1973). Issues in marketing's use of multi-attribute attitude models. Journal of Marketing research, pages $428-441$.

Williamson, O. E. (1993). Calculativeness, trust, and economic organization. The Journal of Law and Economics, 36(1, Part 2):453-486.

Zahavi, A. (1975). Mate selectiona selection for a handicap. Journal of theoretical Biology, 53(1):205-214. 